\title{
大同特殊鋼における $\mathrm{OA}$ 化の状況
}

日下部正気*

\section{Outline of Office Automation in Daido Steel}

Seiki Kusakabe

\author{
Synopgis
}

Daido Steel has introduced stand alone type of word processor since early 1980's in order to improve the efficiency of staff duties.

Thereafter we have put package softwares to practical use, which have the functions of spreadsheet, data processing, graphic design, and so on.

Recently most staff people can make the most use of those softwares as education advances and number of intelligent terminal increase.

This paper describes the short history of our OA (Office Automation) application and the outline of our recent topics which covers electronic communication (electronic mail, electronic bulletin board) and EUC (End User Computing).

\section{1. 緒官}

大同特殊鋼（株）における OA 化は，事務所部門 の業務効率化運動が始まった1985年以降から，順 次展開されてきた. 業枒効率化の観点としては， 基幹業務と部門・個人業務領域に分類されるが， 本稿では部門・個人業務の $\mathrm{OA}$ 化を中心に述へ る.

個人業慗の効率化を推進する上で，ホストコン ピュータメーカ提供の OAソフト活用を柱とし て，利用人口・利用機器の拡大を行ってきており， 現在では，事務所部門のほほ全員が提供ソフトを 活用するまでに至っている。また，最近ではクル ープウエアとしての業務效率化を狙った電子コミ エニケーションシステムの導入やエンドューザー

1994年 4 月26日受付

*大同特殊銅侏情報システム部
コンピューテイングの試行を始めておうう，その概 要を述へる。

\section{2. $\mathrm{OA}$ 化の歴史と变要}

\section{1 第 1 期（単体機器の萁入）}

1981年から本恃部門で，日本語ワープロ・英文 ワープロ專用機の導入に始まり，各事業所人も順 次専用ワープロを中心に展開した. その後も利用 人口の桩大に伴い機器羊入要求は增加の一途であ ク，小型で安価な卓上ワープロに切換之機器堌設 を行ってきている.

また，文書保存としての光ディスク苦置も中央 研究所に初めて設置され，各事業所八も順次導入 されている.

現在では, 約870台のワーブロ專用穖と10台の光 ディスク装置が稼㗢している. 


\section{2 第 2 期(ホスト電算機による技術スタッ ᄀ支援)}

1982年に，品質情報管理システム（QUINT： QUality INformation managemenT system) 開発した，品質解析自体は，以前よりバッチ处理 にて提供していたが，解析に時間がかかることや データ不足もあり問題があった。

そこで，技術スタッフへの支援強化のために， リアルタイムで検索・解析を可能にしたシステム である.システムはホストコンピュータで構筑し ており，解析のためのデータも生産管理システム との併用をやめ解析専用データベースを作成し た。

\section{3 第 3 期（単発業務作業の改善）}

ホスト専用端末が多機能端末としても利用可能 になった1983年から本社部門でホストメーカ提供 のOAソフト LAN シリーズ (NEC系)を導入し 始め, 他事業所でも MAPPER (UNISYS 系), PLANNER-EPOC (FACOM 系)の試行を行って いた，OA 機器としてワープロ・表計算・グラフ描 画が可能であり，評洒は高かったが，多機能端末 としてはまだまだ高価であり，ローカルな試行に とどまっていた。

おりから，1985年の円高不況が始まり，全社的 に事務部門の効率化運動が展開され，個人業拐の 効率化ツールとして本格的導入を決定した。

以降，多機能端末への切換之とOAソフト教育 の展開を行っている．普及にあたって，

全社的には

・新入杜頁教育での義務づけ

$$
\text { 初級 } O A \text { とフォローアップ教育 }
$$

・能力開発課による自己申告講座開講

・広報として，OAかから版（1回／3ケ月）の 発行

各事業所では

・OAルームの設置

・女性インストラクターの配置

・年間計画に基づく OA 教室の開催（現場事務 所を含む)

教育としては，1991年までに，ほほ全員の教育 が完了し，現在でも新人教育・自己申告講座は継 続して実施している。

なお，多機能端末の台数は，現在4.5人/台の割 合になっている.

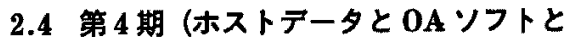 の結合)}

一方，ホストデータ利用の点では，情報システ ム部に对象デー夕を作成依頼する必要があるた め，あまり拡大していなかったが、リレーショナ 儿型 DBの探用（1986年〜）が始まり，自ら対象 デー夕抜出しが可能になったことや，QUINTシ ステムで抽出したデー夕を直接利用できるように したことにより，ホストデー夕を活用した業務改 善も普及している。

主なデータとして，受注・売上の営業情報 (MASCOT), 各工場の生産実䋶・品質情報など の利用が多い.

OA ソフトの利用謤境・構成を图1に、データ利 用比率を图 2 に示す。

また，OAソフトをメインッールとして小口睛 買業務や民生品管理システム(MARIONET)，王 子工場のコードリール部品管理システムなどが構 築是れている。

\section{OA 化 事 例}

3.1 電子コミュニケーション

情報伝達の迅速化・一元化を狙いとして，1991 年から技術サービス部門では，部門の情報交換シ ステムとしてGS-NET (Global Stars NET work system）を稼働させている. 図3からわか るように，社内回線・一般電話回線と市販ソフト を用いたパソコン/ワープロ通信による構成であ る.

システム構筑にあたっては，商用ネットによる 実現も可能であるが，運用面・利用料金などから 独自のネットワークとした，また，端末機は広く 普及していたラップトップワープロを活用し，ス ムーズな利用拡大が図られた。

利用者は，技術サービス部門の約80名全貝であ り各個人がワープロで作成した文書をサーバに登 録し，ペーパレスで相互間の情報交換を行ってい る. 自宅・客先からも利用でき，報告書作成や情 報交换のための出社を不要とした。

勤務時間や地域に拘束されることなく報告・指 示ができ，業務上なくてはならない支援ツールと なり，国内のみならず，海外颋点や海外出張者の 利用も頻繁となっている。 主要な利用機能 


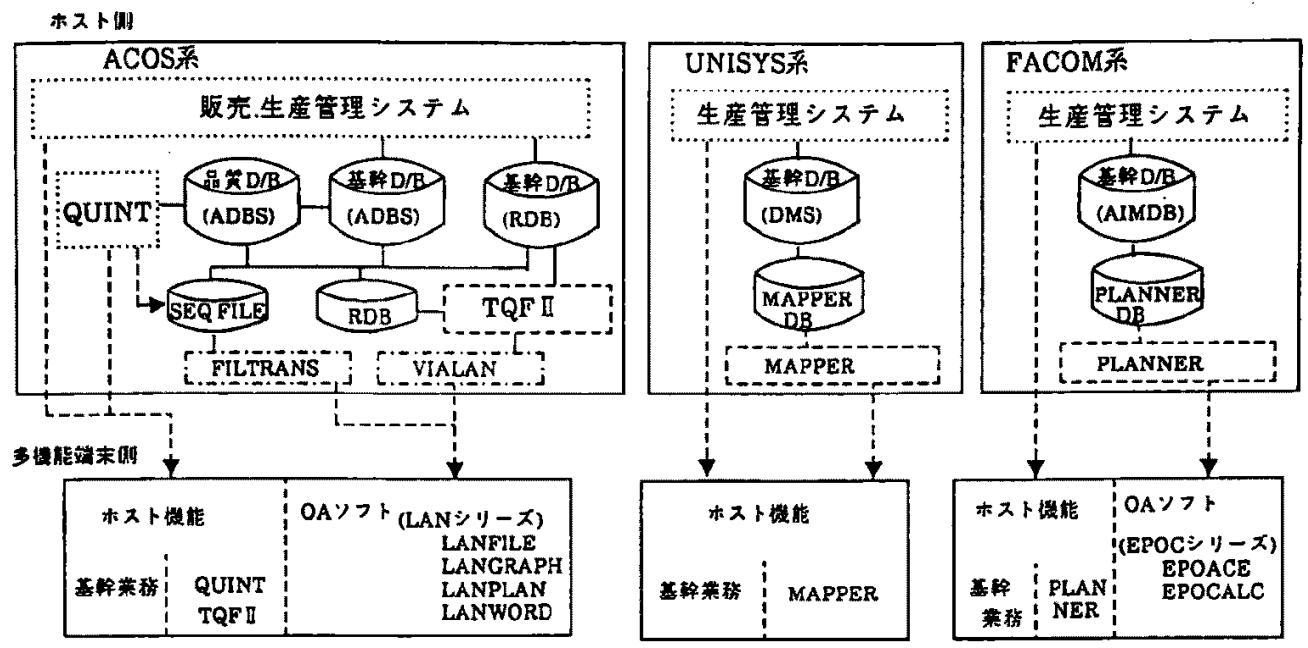

図1 OAソフトの利用璄境・構成

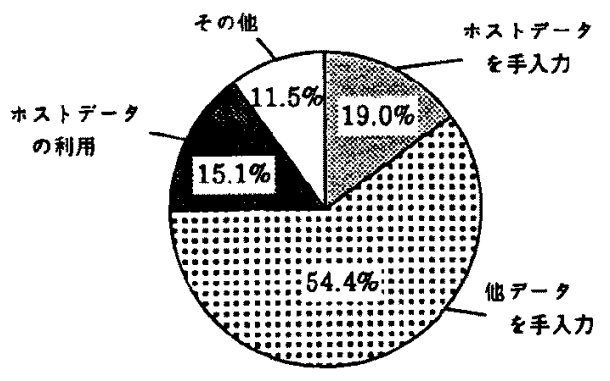

图2 OA フトトのデータ利用比事

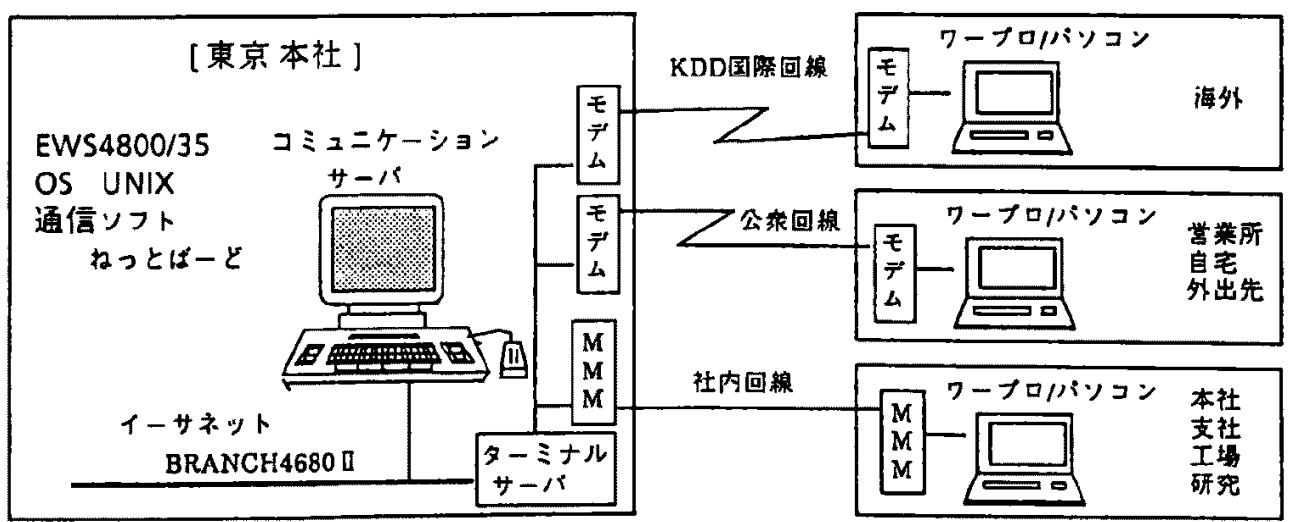

图 3 GS-NET 構成 
（1）電子揭示板

・業務報告

・連絡メモ

・行動予定

・調查低頼

(2) 電子メール

業務報告書データベース

部門全員への揭示連絡

各自のスケシュール

依頼書と進捗

・個人・グループへの連絡

電子コミュニチーションシステムとしては，他 に素形材事業部の「ソジネット」, 情報システム部 の「テムネット」も稼働しており，利用桩大の状 況にある。

$3.2 \operatorname{EUC}($ エンドューザコンピューティング)

$\mathrm{OA}$ ソフトを活用した業務改善は，十分な成果 を上げているが, ホストデータの活用・ソフトの 柔教性・应張性などから下記の上うな問題も顕在 化していた.

・RDBのデータ抽出は，容易でない

・ホスト基幹 DBからのデー夕抽出は，情報シ ステム部門に作成体頼が必要

・大量データは, 転送時間がかかる

・ソフト間でのデータ交換が䋈䊒

また，一方で最近登場のクライアント・サーバ システムを利用することにより，スタッフ自身が より容易にコンピュー夕を活用して、テ゚ータ抽 出・整理・加工・報告文書作成などを効率的に遂 行できるつまり「必要な時に」「必要な人が「欲 しい情報を」「欲しい形で】入手できることをうた ったエンドューザコンピューティングかが找術的 に実現可能なレベルに進展してきていた。

エンドューザコンピューティングは，スタッフ 支援だけでなく，情報システム部門にとっても生 産性向上に奇与する有效な手段となりえる找術で あり，1993年より知多工場にて生産品質情報バン クシステムをEUCのパイロットケースとして, 图4に示すようなシステム構成で試行している， システム構築にあたっては，クライアント・サ 一バ技術がまだ発展途上であることと，将来への 展望を配虑し, 次の点を念頭に惪いた。

(1) データ構築

・スタッフ業務に必要なデータは常に変化する ものであり，加エデータでなく基となるデータの 累積とすること

・データ自身の公開は重要であり, 公開デー夕 を容易に知ることができ，またデータの収集項目

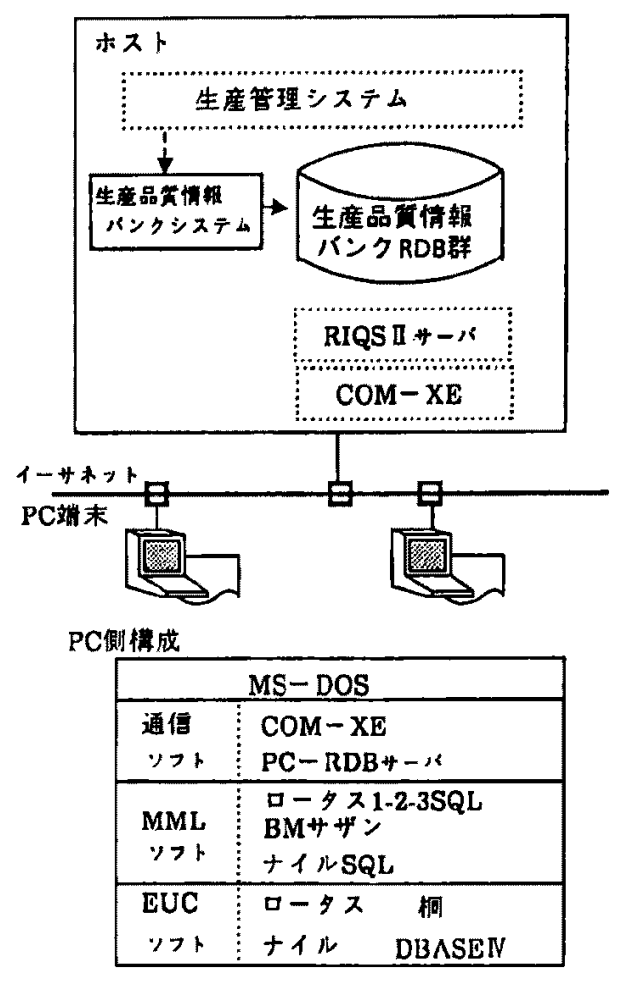

目4 エンドューザコンビューティング榙成

追加・累積も容易に対応できること

・データは，ホスト㑡・サ一バ側とどちらでも 容易に配置変更が可能であること

(2) スタッフ支援ソフト

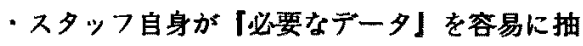
出できることはもちろん，加工・解析および日本 語処理・グラフ处理などビジニアルな形の出力も 容易である．また，定例業務としてもユーザ自ら が構築できる。

・ソフト自体は，教育・サポートを実施してい く上で標準ソフトを限定するが，基本は利用者の 好みとし将来とも固定しない。

現在，生産品質情報バンクシステムとしては， 生産管理室・製銅室向けに，16表のデー夕提供に なっており，今後各室への部門 $\mathrm{DB}$-事業所 $\mathrm{DB} の$ 構筑と既存 RDB を含めたデー夕解故を順次実施 する予定である.

DB 配置では EWS 側への分散方法，クライア ント側 PCソフトとして Windows 对応ソフトな 
どへの移行も課題であるが，スタッフ支㩖技術の 主流として，今後本格的な全社展開が必要である。

\section{4. 最近の OA 化動向と今後の展開}

業務奻率化として最近話題のリエンジニアリン グも象徵されるように，口スタイムの排除・情 報の共有化・同時化業務の追求など，サイクルタ イム短縮》を実現するための電算化ツールがます ます求められている。一方技術的には，広带城ネ ットワーク化によるインフラ基盤の充実とワーク ステーション・パソコンの高機能化によって文 字・図形データから音声・映像データを扱うマル チメディア対応のシステム事例が見受けられる。 列之ば，電子メールシステム間の相互接続》によ ク社内・社外も机上のパソコンで送受信できると か,パソコン画面から指定した相手に電話をかけ, 共有ウインドウ画面上でお互いの顔とデータを見 ながら協議するマルチメディア会議システム4)が 可能になっている.

情報連絡方法・情報活用方法の選択肢が多岐に 渡り，今までのような全社同一の形態ではなく， 各事業部・部門の特性にあったどのような形態を 導入するかがポイントである.

$\mathrm{OA}$ 化推進にあたっては，インフラ罢境なども 重要な要素であり，当杜に扔いても情報通信ネッ トワークのさらなる整備と DBサ一バ・文書サー
パ・コミュニケーションサーパとしてのワークス テーション利用技街の蓄積を進め，最終的な姿を しっかり描いておくことが重要と考えている.

\section{5. 結}

\section{言}

事例における䉓子コミニニケーション・エンド ユーザコンピューティングから，業務好率化を推 進する上で，非常に有効なツールであることを確 信した，また，技術ノウハウとしても蓄積ができ たと考えている.

しかしながらこれれら OA 化のハード・ソフト はまだまだ半製品の状態であり，価格面の動向も 合め流動的である．また，利用者側への情報利用 教育も大きな課題といえる。

以上のことを十分に認識して，今後の全社展開 を計りたい.

\section{(文献)}

1）木暮 七，日経コンピュータ (1992.3.9) 197 -231, (1992.4.20) 141-154

2) 小林 裕, リエンジニアリング(1994)〔中経 出版了

3) 堀純一郎, 日経コミュニケーション 161 (1993) 36-39

4) 渡辺博則, 日経コミュニケーション $161(1993) \quad 26-32$ 